\title{
INNOVATIVE AND \\ SUSTAINABLE ENERGY \\ TECHNOLOGIES: THE ROLE \\ OF VENTURE CAPITAL
}

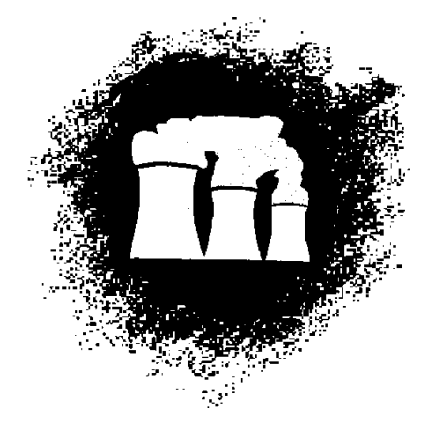

Bill Moore* and Rolf Wüstenhagen

University of St. Gallen, Switzerland

This paper provides an overview of a multi-year research project being conducted at the University of St. Gallen, Switzerland. The objective of the research is to evaluate the role of financial structure in promoting the development of innovative and sustainable energy technologies and its current relationship to innovation and entrepreneurial activity in this important economic sector. In this paper, emphasis is placed on the venture capital segment of the capital market and the electricity segment of the energy industry. We first provide a short overview of the electricity sector. We then briefly discuss the concept of innovation and entrepreneurship and its relationship to our research effort. Finally, the bulk of the paper outlines the conceptual framework for the venture capital element of the research project. We conclude the paper with a summary of our preliminary observations. Copyright (C) 2004 John Wiley \& Sons, Ltd and ERP Environment.

\footnotetext{
* Correspondence to: Bill Moore, Institute for Economy and the Environment, University of St. Gallen, Tigerbergstrasse 2, CH-9000 St. Gallen, Switzerland. E-mail: moorebill1@aol.com
}

Received 4 March 2004

Revised 22 March 2004

Accepted 14 April 2004

\section{ELECTRICITY}

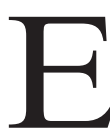
lectricity ${ }^{1}$ is one of a limited number of important factors of production that enable economic development. The annual market for the purchase and sale of energy is an estimated $\$ 1.5$ billion (Worldwatch, 2003). In the US alone, the electricity sector represents approximately $7 \%$ of GDP (Stuebi, 2001). Fossil or carbon based fuels are used to generate well over one-half of the electricity produced worldwide. Renewable fuels (e.g. solar, wind, water) provide a relatively small percentage of the total electricity generated and consumed. The overall forecast growth rate of electricity generation over the next 25 years is fairly high; forecasts consistently show renewable energy sources growing at a much faster rate than other sources. Most scenarios suggest that renewable energy sources will not, however, represent a signifi-

\footnotetext{
${ }^{1}$ Throughout this paper, the terms 'electricity' and 'power' will be used interchangeably. We occasionally refer to the broader term 'energy', which includes electricity and other forms of energy, including thermal and kinetic. This is due to the fact that many energy conversion technologies provide both electricity and heat. Our focus in this paper is on electricity.
} 


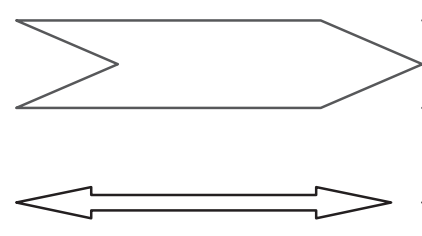

Supply-side

'Grid'

Demand-side

- Fuel

procurement

- Fuel

transportation

- Generation

- Controls
- Transmission

- Substation

- Distribution

- Controls
- $\quad$ Metering

- Optimization

software

- On-site generation

- Conservation

Figure 1. Electricity value chain

cantly higher penetration rate by 2025 because their growth starts from a relatively low penetration base.

\section{A short history of electricity}

The introduction of electricity generation, transmission and distribution systems required the building of an entirely new industrial and production philosophy, the most significant contributions to which were made by a number of individual inventors beginning in the late 1800s (Smil, 1994). During the 1900s electricity innovations focused primarily on increasing scale (in generation and distribution) to drive down costs (Hirsh, 1989). By capturing economies of scale and driving down costs, the electricity industry was able to consistently lower prices, which encouraged rapid growth in the use of fossil fueled production. The relative cost advantage to fossil fuels persists.
The electricity value chain

The electricity value chain is complex, capital intensive and complicated by the fact that opportunities to store electricity are currently limited. Electricity must be delivered and consumed as it is created. A simplified electricity value chain is shown in Figure 1. Subsystems (generation, transmission and distribution) and processes are highlighted.

Venture capital driven investment opportunities may exist at each step in the chain and an innovation at any step can improve the system's overall efficiency. From Figure 1, opportunities to innovate at all steps along the value chain can be identified. Take offshore wind energy as an example. Investment opportunities might exist in generation technologies (innovative wind turbines and components) as well as in grid connection solutions. Enabling technologies such as power electronics or control software may also be attractive to venture capitalists. In some cases, new tech- 
nologies may leave parts of the current value chain redundant. For example, distributed generation with building-integrated solar cells might reduce the need for transmission capacity. New technologies on different parts of the value chain can also complement each other, such as solar energy and new energy storage technologies.

\section{Growth in the use of fossil fuels}

Today, most electricity is produced using fossil fuels that are limited in supply. Nuclear energy is also a common production source, but its use as a fuel is controversial. Nuclear energy produces small amounts of greenhouse gases, but creates other undesirable byproducts including fuel storage and waste disposal constraints and risk of accidents. The use of fossil fuels is a significant source of pollution in various forms in addition to creating several other undesirable byproducts including supply related security risk.

\section{Electricity generation mix today and in the future}

Fossil fuels are used to produce about $64 \%$ of the world's net electricity generation. Renewable energy accounts for 19\%, the vast majority of which comes from hydroelectric power plants. Faster growing 'new' renewable energy sources such as wind, geothermal, solar and biomass currently account for less than $2 \%$. Nuclear power accounts for the remaining $17 \%$ (IEA, 2002). The share of renewable energy sources in electricity generation varies considerably from region to region.

Worldwide electricity consumption is projected to grow at an average annual rate of $2.4 \%$ from 2001 to 2025, with the highest annual rate of growth occurring in Asia generally $(3.7 \%)$ and China specifically $(4.3 \%)$. The Global Energy Perspectives published by IIASA and the World Energy Council demonstrate the wide range of long-term options for global electricity generation up to the year 2100. Figure 2 shows the results of two oppo- site ends of the spectrum that they have identified; a high-growth scenario with large shares of nuclear and coal (A2) and an environmentally driven scenario with lower overall growth and renewable energy sources and natural gas becoming the preferred fuels (C1). The overall results differ significantly by 2050 , with total electricity production ranging from 23830 to 41 976 Terawatt hours. Nonetheless, the share of renewable energy sources is expected to grow in all scenarios compared with today, accounting for $30-57 \%$ of electricity generation in 2050 (including hydropower).

\section{SUSTAINABLE ENERGY TECHNOLOGIES}

There are different approaches to defining sustainable energy. In very general terms, it can be defined as those technologies that reduce environmental impacts, are socially acceptable and can be economically competitive. Following Pfeuti et al. (2002), this broad definition of sustainable energy can be classified into four main clusters: renewable energy, distributed energy systems, natural gas and demand-side energy efficiency. The four clusters tend to meet the definition of sustainable energy better than fossil- or nuclear-based power technologies in that they usually reduce environmental impacts, tend to be more socially acceptable and have a good chance of being economically competitive, increasingly so if environmental externalities are internalized.

Renewable energy is probably the category most often associated with the term sustainable energy. Renewable energy sources such as wind, hydropower, solar and geothermal energy are available in large quantities and are virtually $\mathrm{CO}_{2}$ free. Each of these technologies presents opportunities and challenges. Distributed energy systems bring generation closer to end-users, which promotes more efficient uses of heat and helps to ensure a more reliable supply. Distributed generation is also a good solution for supplying power in emerging 

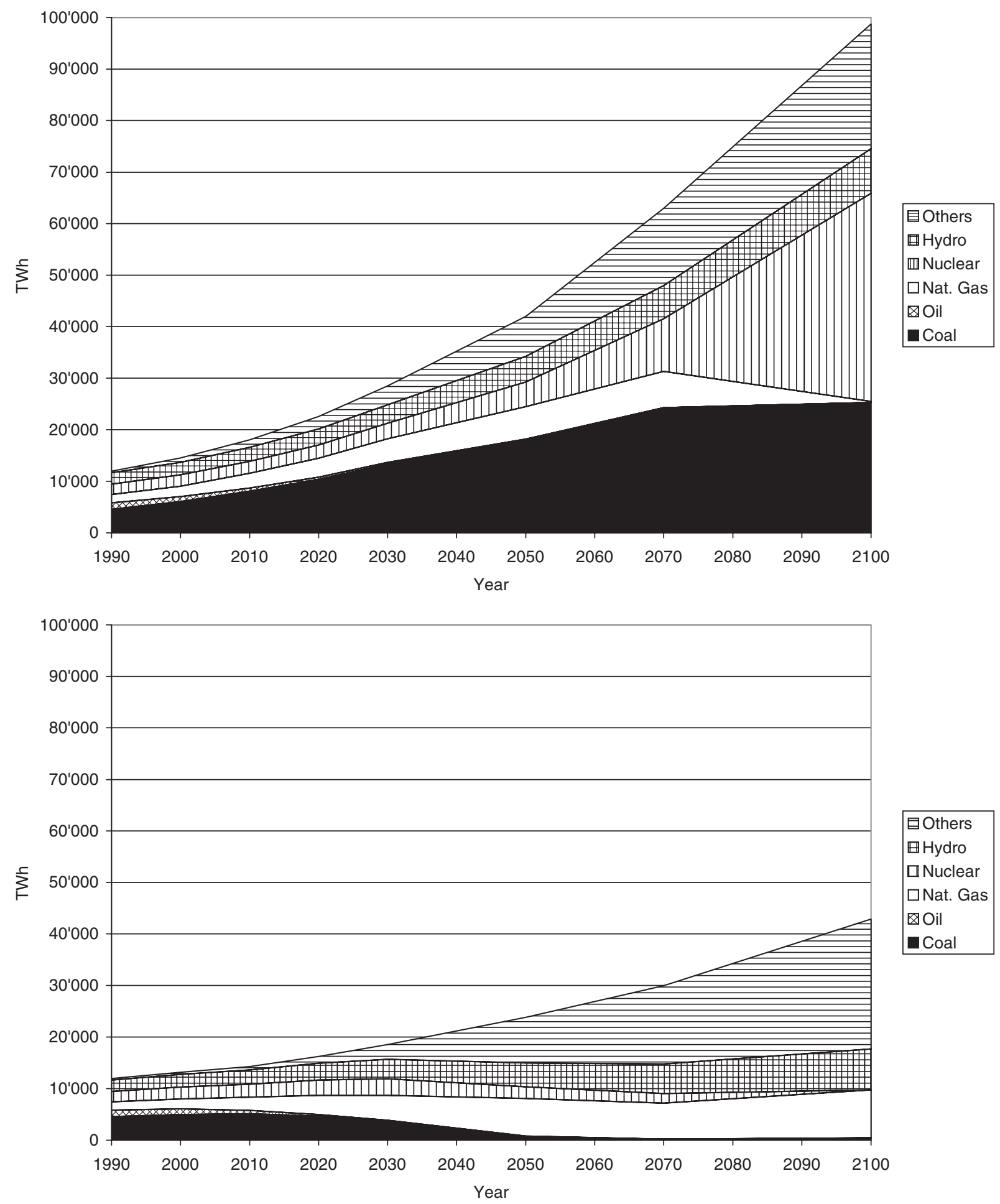

Figure 2. Total world electricity production 1990-2100, according to IIASA/WEC Scenarios A2 and C1 (source: IIASA/WEC Global Energy Perspectives, 1998) 
markets when grid infrastructure is not in place. Along with microturbines, fuel cells and other innovative micro-generation devices, new storage technologies and highperformance electronic systems also fall into this category. Natural gas will play an important role in the medium term because of its lower carbon content compared with other fossil fuels. Replacing coal with natural gas is thus an effective step towards addressing the issue of climate change. Natural gas is also the fuel of choice for many decentralized energy technologies. Finally, demand-side efficiency includes technologies and services for facility management to improve energy efficiency: heating systems, new insulation materials, contracting services and energy management systems.

\section{FINANCIAL STRUCTURE}

Developing a broad understanding of how financial structure impacts the investment environment for innovative and sustainable energy technologies is important because investments in new sustainable energy technologies are not made in a vacuum. Fundamentally, we know that expected rates of return and risk drive the rational investor's investment decision-making process. We also know that significant amounts of capital are invested in fossil fuel and nuclear generating capacity but that the amount of investment made in early stage innovative sustainable energy projects is significantly smaller.

The financial structure of an economy provides the macro-level context within which investment funding is forthcoming for relatively high risk, but groundbreaking and innovative research that can lead to the invention and commercialization of new cost-effective sustainable energy technologies. The financial structure of an economy, through provision of capital, risk, return, taxes and liquidity, can bring significant change to the electricity industry to reduce reliance on limited fossil fuels, and to reduce the incidence of pollution or, alternatively, to impede its progress. Taken together, the elements of financial structure fundamentally influence risk-return analyses and hence investment prospects.

\section{Electricity and capital markets}

In a general sense all segments of the financial market have a stake in energy and there is, therefore, a growing level of interest in the indirect financial implications of fossil fuel use and renewable energy. The primary factor driving this activity is a growing awareness of the possible link between greenhouse gases, the use of carbon-based fuels and risk. Increasingly, investors, commercial banks and investment banks are carefully considering the connection between fossil fuels and environmental problems, and how it might impact key financial market stakeholders. For purposes of the balance of this paper we will focus on venture capital, the equity risk segment of the capital market.

\section{INNOVATION AND ENTREPRENEURSHIP}

The innovative process and the entrepreneur are critical links between the current state, and a desired state, of electricity production. Therefore, we will look at how well the financial structure of the economy supports the entrepreneur and the innovation process. Levine (as summarized in Smith and Smith, 2000) suggests that a financial structure most likely to stimulate entrepreneurial activity in an economy will embody activities that provide for facilitating assessment of the risks and rewards of prospective ventures, limiting exposure to risk and increasing expected returns, facilitating and limiting risk-taking by the entrepreneur, including patient investors with minimal need for liquidity, including a tax structure that favours capital investment, 
facilitating diversification and pooling of risks, providing easy access to well functioning public capital markets and encouraging predominantly market driven investment decisions.

\section{VENTURE CAPITAL}

The venture capital function of a capital market provides investment funding for relatively high risk, but often groundbreaking and innovative, research that may eventually lead to the development of young companies that produce and market new cost-effective sustainable energy technologies. The venture capital segment of the capital market has received a significant amount of attention lately owing largely to the extremely high rate of growth in venture capital investments, and the number of venture capital companies and significant absolute amounts of risk capital employed during the Internet and e-commerce boom of the late 1990s. Historically, venture capital and all forms of new venture financing have played a critical role in new business formation and technological transformation.

The cash invested in venture capital typically comes from investors with long investment horizons. Pension funds, insurance companies, endowments and wealthy private investors are typical sources of venture capital. The invested capital is normally placed in a fund with a limited life and a specific investment objective. The typical energy venture capital fund is managed by a specialist firm (e.g. Nth Power and SAM), a general venture capital company with a division that specializes in energy (e.g. Perseus LLC and Beacon Capital) or an electric utility that chooses to self-sponsor a venture capital fund (e.g. Hydro-Québec CapiTech and Cinergy Ventures). Venture capital can be invested in the $R \& D$, start-up, early and later stages of a firm's development and a venture capital company will typically allocate certain amounts of capital to each stage.

\section{Electricity and venture capital}

Over the past ten years a number of new venture capital funds have emerged in Europe and North America that are specifically targeting sustainable energy technologies as an investment theme. A significant number of such venture capital firms now exist. For example, the Financing Sustainable Development Energy Directory (www.fsedirectory.net) lists, as of 15 July 2003, over 50 firms willing to consider private equity investments in a full range of sustainable energy projects including all forms of renewable generation and energy efficiency. Alternative sources of data yield different lists, and we expect to eventually find well over 100 firms that now make private equity investments in renewable and sustainable energy projects and young companies.

In the year 2000, venture capital firms invested approximately $\$ 100$ billion in new businesses. A little more than $1 \%$, or $\$ 1.2$ billion, was invested in energy companies. Approximately $90 \%$ of that investment was made in later-stage financing rounds (pre-IPO for example), not seed and early stage efforts (Stuebi, 2001). With such small amounts of capital invested in sustainable energy one must question whether venture capitalists have a substantive role to play in promoting sustainable energy.

\section{Why are venture capitalists interested in energy?}

Venture capitalists seek high-risk opportunities and expect to receive high returns on their investments in exchange for taking that risk. Several key factors are driving the increasing, albeit still rather small, emphasis on sustainable energy technologies by venture capitalists. Three factors regularly dominate the discussion: deregulation of the power markets, environmental pressures and security needs. Each of these factors has created an opening for some form of innovation in the electricity value chain. 
- Deregulation of the power markets creates opportunities for investors that were previously shut out of the generation market.

- Environmental concerns, particularly global climate change, are high on the agenda for governments and non-governmental organizations in both industrialized and developing countries.

- Security concerns relative to the predominantly central station configuration have increased post-9/11.

Studies show that venture capitalists demand very high rates of return for the risk they take. Holding periods for the investments are typically in the range of five to eight years although the holding period expectation is a function of the stage at which the investment is made (Smith and Smith, 2000). Although venture capital companies require high rates of return, they do not always get them. Studies show that actual rates of return are much lower than required or expected returns (Kaplan and Schoar, 2003).

\section{What do energy venture capital companies invest in?}

Energy venture capital companies invest in a wide range of innovative energy projects all along the electricity value chain. The overall theme of these investments is consistent with strategies to improve the efficiency of power systems or to reduce the use of fossil fuels by switching to more environmentally benign sources of power. Generally, the investment universe may include renewable energy, distributed generation, energy storage, demandside management, transportation and certain enabling technologies.

\section{How much do energy venture capital companies invest?}

The overall level of venture capital funding grew rapidly then fell in the late 1990s and early 2000s. From a level of $\$ 10$ billion in 1996, venture capital investing in the US grew to a high of $\$ 105$ billion in 2000 then fell to $\$ 41$ billion in 2001 and $\$ 20$ billion in 2002. Most of the investments were made in technology, software and biotechnology companies, a trend consistent with historical practices.

According to Clean Edge (2003), venture capital investing in energy as a percentage of total venture capital investing continues to grow in the US, although the absolute amounts are decreasing. Clean Edge reports total venture capital investing in energy technology at $\$ 204$ million, $\$ 442$ million, $\$ 1,200$ million, $\$ 774$ million and $\$ 488$ million for the years 1998, 1999, 2000, 2001 and 2002 respectively. At these investment levels, energy technology investing accounted for $0.9,0.7,1.2,1.9$ and $2.3 \%$ in each of these years respectively ( $\mathrm{PwC}$ MoneyTree Surveys, National Science Foundation, Nth Power and own analysis).

According to a sample of the guidelines published by energy venture capital companies, they typically commit from $\$ 1$ to 5 million per investment, although we found examples of amounts both higher and lower than these general guidelines. The level of flexibility implied is consistent with the general practices of venture capital firms. Some recent examples of sustainable energy companies receiving funding include Evergreen Solar (raising \$28 million in a PIPE ${ }^{2}$ in 2003), Green Mountain Energy, a retail provider of electricity produced from renewable sources (received \$24 million in 2002), Konarka Technologies, a photovoltaic manufacturer (received $\$ 13.5$ million in 2002), and Polyfuel, a fuel cell developer (received $\$ 15.6$ million in 2002).

\section{Recent experience with energy venture capital investments}

In general, when we look at the recent history of investments made in the sustainable energy area, the news is not encouraging. A summary

\footnotetext{
${ }^{2}$ Private Investment in Public Equity; i.e., the company did a private financing round with venture capitalists despite the fact that they are listed on the stock exchange.
} 
Table 1. Price experience for selected sustainable energy IPO investments

\begin{tabular}{lcccc}
\hline Name & IPO date & IPO price & Hi price & $\begin{array}{r}\text { Current price } \\
(18 \text { July 2003) }\end{array}$ \\
\hline Active Power, Inc. & 17 Aug 2000 & $\$ 17$ & $>\$ 70$ & $\$ 1.59$ \\
Capstone Turbine Corp. & 28 June 2000 & $\$ 16$ & $>\$ 90$ & $\$ 1.08$ \\
Evergreen Solar, Inc. & 2 Nov 2000 & $\$ 14$ & $>\$ 20$ & $\$ 1.45$ \\
Plug Power & 28 Oct 1999 & $\$ 15$ & $>\$ 160$ & $\$ 4.65$ \\
Proton Energy Systems & 29 Sept 2000 & $\$ 17$ & $\$ 2.26$ \\
\hline
\end{tabular}

Source: Yahoo, Company Websites.

of the experiences of a sample of recent sustainable energy IPOs is shown in Table 1.

We can see from the data that the companies were all trading well below their peak prices in July 2003, in at least one case over $\$ 150$ lower. Second, all of the companies in this small sample were trading well below their IPO price (which is not necessarily the price on which they traded during the first trading day). In fairness to these companies, their fate has been tied closely to the overall stock market, which experienced a similar fate over this same time period. It is clear, however, that investors in these sustainable energy companies will find it difficult to overlook such dismal results.

\section{What strategies do energy venture capital companies employ?}

A quick and informal survey of a small sample of venture capital companies ${ }^{3}$ that invest in energy either as a primary activity or as a line of business shows that they have adopted strategies similar to each other and to venture capital generalists. Three features stand out. First, each firm declares an interest in investing in new ventures. Second, each firm represents itself as an active investor, a feature of venture capital investing not present, for example, when an investor buys the stock of a

\footnotetext{
${ }^{3}$ The sample included Nth Power (http://www.nthpower.com/ nth_strategy.html), SAM Private Equity (http://www.samgroup.com/e/priveq/strategy.cfm), Cinergy Ventures (http:// www.cinergy.com/Energy_Merchant/default.asp) and Draper Fisher Jurvetson (http://www.dfj.com/about/a_philosophy_ frset.html).
}

listed company, and third, each suggests that it brings a value added network to the effort.

The value added features identified in the four strategy statements are typical of the representations made by most venture capital companies: in addition to capital, venture capital firms usually provide access to their accumulated experience and expertise, networks and reputation. As indicated by Timmons (1999), 'Classic venture capitalists work as coaches and partners with entrepreneurs and innovators at a very early stage to help shape and accelerate the development of a company'. The proposition that venture capitalists add value is consistently supported in the literature. Studies also show that venture capitalists contribute to faster professionalization of start-up firms (Hellmann and Puri, 2002), that VC backed companies introduce more radical innovations and apply more aggressive marketing strategies (Hellmann and Puri, 2000) and that each dollar of R\&D money invested in VC backed firms generates more patents than the same investment in other companies (Kortum and Lerner, 1998). Additionally, Gompers and Lerner (2000) show that 'returns on nonventure IPOs are significantly below those of venture-backed IPOs and below relevant benchmarks when returns are weighted equally'.

What is the investment process?

A typical energy venture capital fund management company is staffed with people who have 


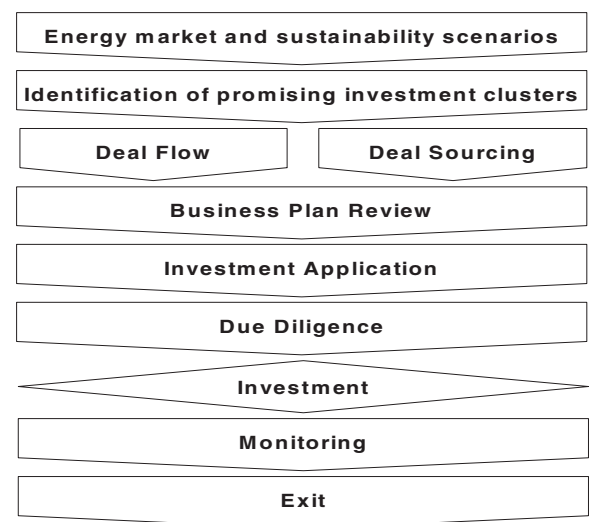

Figure 3. Typical energy venture capital investment process

experience in the energy industry. Alternatively, a venture capital company that does not specialize in energy ('generalist') will retain a smaller staff of individuals who may have some expertise in energy but may also be responsible for other sectors. Generalist venture capitalists often work with external consultants on specific investment projects, whereas a specialized energy venture capitalist would rather rely on in-house expertise.

The typical energy venture capital investment model follows a straightforward asset allocation process: ${ }^{4}$ establish objectives, examine the financial, economic, political and social conditions and finally construct the portfolio and monitor performance.

As shown in Figure 3, most energy venture capitalists start with market analysis, which may also include a scenario analysis of energy and sustainability trends. As a result of this, the venture capitalist identifies high potential investment clusters. Within these clusters, the venture capitalist both actively sources deals (e.g. by hosting or attending venture fairs and industry conferences, doing internet searches)

\footnotetext{
${ }^{4}$ Asset allocation is the process of deciding how much of the fund's cash is invested in specific technologies, geographical areas and specific companies. The outcome of the asset allocation process is a basket of investments with a specific return and risk profile.
}

and passively receives deal flow (i.e. firms send their business plans and requests for funding). The business plans of ventures that fit the venture capitalist's investment profile are then reviewed and discussed within the team. If the initial analysis is positive, an indepth assessment leads to an investment application that is formally considered by the fund. In the case of a positive decision (typically $1-2 \%$ of all submissions), the venture capitalist proceeds with a due diligence process and finally makes an investment in the company. After the investment is made, the venture capitalist actively works with the entrepreneurs to grow the company. Finally, at the end of the investment cycle, typically after 5-8 years for early and expansion stage investments or 1-2 years for pre-IPO investments, the venture capitalist exits the investment either through an IPO or a trade sale.

\section{What is government's role?}

Governments play a role in the venture capital market, either directly by acting as venture capitalists, or indirectly by implementing a number of programmes that influence the economics of energy investments. Governments have a long history of providing 'venture capital' directly. In the US, the federal government has historically played an active role in new venture financing through the US Small Business Innovation Research (SBIR) programme. Studies have shown evidence of positive effects.

Government policies can also indirectly influence the energy venture capital market since a number of environmental and energy policies can assist in making investments in sustainable energy ventures more or less attractive. These indirect influences include taxes on fossil fuels, incentive schemes for renewable energy generation, emissions trading and green certificates, covenants (i.e. 'voluntary' environmental agreements between industry and government), investment subsidies and R\&D subsidies. 
Final comments about venture capital ... for now

The supply of venture capital may be influenced by the health of the IPO market (Jeng and Wells, 2000). The influence is significant and most dramatic on late stage versus early stage venture capital investments. That is, the existence or absence of a viable IPO market most significantly influences the provision of late stage venture capital.

Venture capital, innovation and entrepreneurs are logically connected. Kortum and Lerner (1998) looked at 20 industries over a three-year period of time and found that the amount of venture capital activity in an industry significantly increases its rate of patenting' and that venture capital may have a larger influence on innovation than corporate $R \& D$ programmes. These general conclusions are supported by research conducted with German companies (Tykvová, 2000), where the results show that 'venture capital has a significant positive influence on the number of patent applications in Germany'. Clearly, there seems to be a significant role for venture capital to play in promoting innovation.

\section{CONCLUSIONS}

The purpose of this paper was to describe the study that we have initiated to develop a better understanding of how financial structure in general, and venture capital specifically, influences innovation in renewable energy technologies. We believe that this is an important area for study because the overall level of capital investment in sustainable electricity technologies is not sufficient to make a significant difference in the penetration rate of renewable energy and in reducing undesirable byproducts going forward. Our research is intended to enable us to understand why this is the case. We have started to address this question from different perspectives, including interviews with venture capitalists in the energy technology sector, looking at the role of corporate venture capital, comparing energy with other sectors that have been popular for venture capital investing such as biotechnology and information technologies and investigating the IPO performance of sustainable energy technology companies. Given the size of the challenge that lies ahead of the energy sector, there is clearly room for further research.

\section{REFERENCES}

Clean Edge. 2003. Clean Energy Trends 2003. San Francisco. http:www.cleanedge.com/reports/trends2003.pdf

Gompers PA, Lerner J. 1999. The Venture Capital Cycle. MIT Press: Cambridge, MA.

Hellmann T, Puri M. 2002. Venture Capital and the professionalization of Start-up Firms. Journal of Finance 57: 169-197.

Hellman T, Puri M. 2000. The interaction between product market and financing strategy: the role of venture capital. Review of Financial Studies 13: 959-984.

Hirsh RF. 1989. Technology and Transformation in the American Electric Industry. Cambridge University Press: Cambridge.

IIASA. Energy Council. 1998. Global Energy Perspectives; N. Nakicenovic, A. Grubler, and A. McDonald (eds). Cambridge University Press: London.

International Energy Agency (IEA). 2002. Renewables in Global Energy Supply: an IEA Fact Sheet. Paris. http:www.iea.org/dbtw-wpd/textbase/papers / 2002/leaflet.pdf

Jeng LA, Wells PC. 2000. The determinants of venture capital funding: evidence across countries. Journal of Corporate Finance 6: 241-289.

Kaplan SN, Schoar A. 2003. Private Equity Performance: Returns, Persistance, and Capital Flows. Research Paper, University of Chicago, November 2003. http:/ /gsbwww.uchicago.edu/fac/steven.kaplan/ research/prereturns.pdf

Kortum S, Lerner J. 1998. Does Venture Capital Spur Innovation? National Bureau of Economic Research Working Paper 6846.

Kortum S, Lerner J. 2000. Assessing the contribution of venture capital to innovation. Rand Journal of Economics 31: 674-692.

Lerner J. 1996. The Government as Venture Capitalist: the Long-Run Impact of the SIBR Program, National Bureau of Economic Research Working Paper 5753.

National Science Foundation. 1998. Venture Capital Investment Trends in the United States and Europe. http://www.nsf.gov/sbe/srs/issuebrf/sib99303.htm [20 July 2002]. 
Pfeuti R, Flatz A, Moor M, Wüstenhagen R, Zamboni M. 2002. Changing Climate in the Energy Sector - a New Wave of Sustainable Investment Opportunities Emerges, 2nd edn. SAM Sustainable Asset Management: Zollikon-Zurich. http: / / www.sam-group.com/SAM_pdf/SAM sust_studies/Energy_Studie_e.pdf [16 March 2004].

Smil V. 1994. Energy in World History. Westview: Boulder, CO.

Smith RL, Smith JK. 2000. Entrepreneurial Finance. Wiley: New York.

Stuebi RT. 2001. Going to Seed: Building Successful New Energy Companies, speech given at the Alternative Energy Investor Conference, San Diego, CA.

Timmons JA. 1999. New Venture Creation. Irwin-McGrawHill: New York.

Tykvová T. 2000. Venture capital in Germany and its impact on innovation. Paper presented at the 2000 EFMA Conference, Athens, 2000.

Worldwatch Institute. 2003. State of the World 2003, special 20th anniversary edn. Norton: New York.

\section{BIOGRAPHY}

Bill Moore (corresponding author) is a doctoral candidate at the University of St. Gallen and an experienced energy manager. His current research interests include renewable energy, innovation, entrepreneurship and venture capital. He has over 20 years experience in the US energy industry in a wide range of management positions. Additionally, he has worked with many start-up and early stage renewable energy and non-energy companies in financial, operations and strategy roles and simultaneously pursued a portfolio of teaching assignments in the US and Europe. He can be contacted at the Institute for Economy and the Environment, University of St. Gallen, Tigerbergstrasse 2, CH-9000 St. Gallen, Switzerland. Tel.: +41-71-224-2587

Fax: +41-71-224-2722

E-mail: moorebill1@aol.com

Internet: http://www.iwoe.unisg.ch

Dr. Rolf Wüstenhagen is Vice-Director of the Institute for Economy and the Environment at the University of St. Gallen, Switzerland. He teaches corporate sustainability, green marketing and management of sustainable energy. His current research focus is on the role of sustainable entrepreneurship and venture capital in the energy sector. Prior to his current academic position he worked for a leading European Venture Capital and Asset Management company in the area of sustainability investments. He has been involved in the organization of conferences including the First European Conference on Green Power Marketing and the First European Energy Venture Fair and has published extensively.

Email address: rolf.wuestenhagen@unisg.ch 